出来るであろう。㫿問題となる点は本溶媒禾は所謂分配 クロマトグラフィに属さないるので女るということです り，文面白い点は本溶媒系に上ると有機物質も存在する と思われる成分数以上の斑点を生ずるといら類似点であ る8。しかし陰イオンを分離するといら点から見るとき には，本溶媒では結局陽イオンの存在は妨害となり，十

－8）传竹，分析化学 2, 261 (1953); Ha11, Wewalka, Nature 168, 685 (1951).
分除去されていなければ試料液として有効なものとはな らないととになる。今後はこの点に留意し新たな溶媒系 を追求してゆく皘りである。

種々御教示御助言を戴いた静岡大学桜場周吉教授，塩 川孝信博士並びに村田 迪講師に衰心上り感謝の意を捧 げたい。

(昭和 28 年 4 月，日本化学会第 6 年会講演)

\title{
放㫣によるシアン化合物の分解反応の研究（第 $\mathbf{4} ＼mathbf{5}$ 報）
}

\author{
近藤 正 春
}

\section{（第 4 報） 無声放軋によるシアン化 水素の分解反応}

\section{緒}

言

ジアン化水素はダロー放電及び弧光放電によって分解 反応を行う場合については既倍告したが，無声放電に よってる又分解を行らことを認め，乙かるグロー，弧光 放電による場合と可成り相異する点を認奶たので報告す る。

\section{1. 实験}

無声放雪によるシアン化水素の分解の測定 には第 1 報》第1四のガイスレル管Aをジー メンス管に変えるだけで，他は殆えどそのま まに用いだ。ジーメンス管は内容積 $37.55 \mathrm{cc}$ であり放電間陣は $1.8 \mathrm{~mm}$ で岁る。これに 附随しているコック類は放電に対して有效な 部分を增すため，放電間陌に出来る限り近接 して取り付けた。暗黒中に放電を行った結果， ユックの部分を含む反応器全容積にわたって 放電が行わ的ていることを確めた。二次電源 は大型漏洩型变圧器 (短絡電流 $75 \mathrm{~mA}$ ) を 用い,一次側電王をスライダックによって調 整し，放電電圧话びに電流を調節した。

\section{(1) 実験方法}

第 1 報と同様であるが，放電後のシーメン

1) 沂藤, 本誌 74, 138 (1953).
ス管内の気体の圧の測定にもマノメータMを使用し，こ の場合コック $\mathrm{C}_{6}, \mathrm{C}_{7}$ ，及び $\mathrm{O}_{8}$ に囲まれた空間に対す る補正を施した。

(2) 放電状態

以上の装置にて放電を行い，これを暗黒中で見ると無 数の小さい火花が認められ，その色は空気の場合に比較 乙て紫色に富んでいる。なおシアン化水素の压は最低 $20 \mathrm{~cm} \mathrm{Hg}$ で山り，かかる低い王でも無声放電が行われ ているかどらかを見るためにそのオッシログラムをとっ

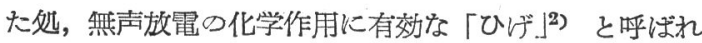
る衝撃波を認め，その点に関しては疑のないことを確め

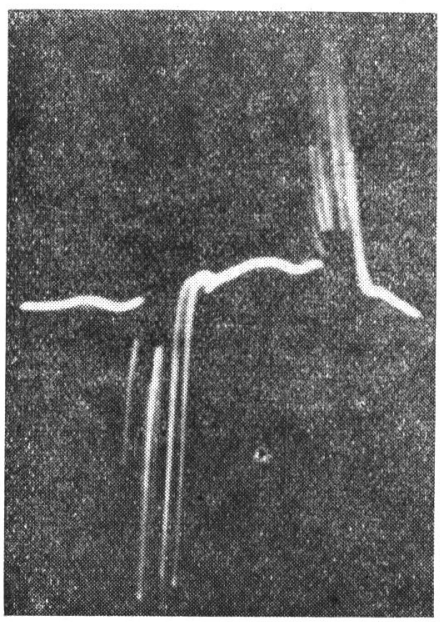

A シアン化水素 $20 \mathrm{~cm} \mathrm{Hg}, 200 \mu \mathrm{A}$ 第 1-I 図

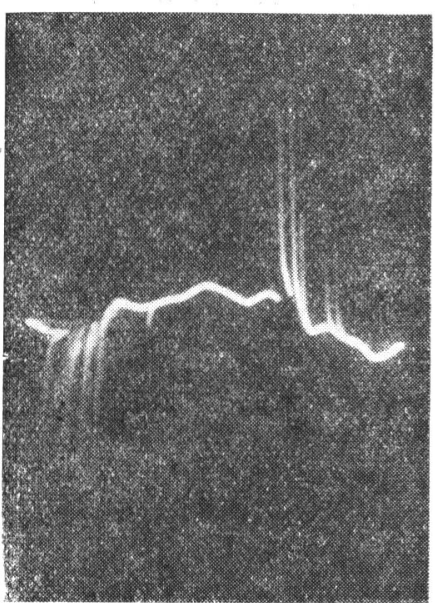

気 第 1 一 II 図

2) M. Suzuki, Proc. Japan Acad. 26, 20 (1950). 
た。第1四はそのオッシログラムであり，比較のために 同じ条件下の空気に関するものを添兑た。

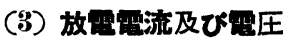

放電電流はグロ一放電に枋に塨合程安定せず，放電 開始後 4 分前後よりかなりの变動を認め大菸合もぬっ た。な打本報の実験に打いでは電流值が放電反応に及ぼ す影響に研究の主目的を置いたため，電冉の值はシフン 化水素の三種の初圧に対して $100,200,300 \mu \mathrm{A}$ の電流 を得るに必要な值を選んだ。

\section{第 1 表}

\begin{tabular}{lllc}
\hline 放電電流 & $100 \mu \mathrm{A}$ & $200 \mu \mathrm{A}$ & $300 \mu \mathrm{A}$ \\
初 压 & & & \\
\hline $20 \mathrm{~cm} \mathrm{Hg}$ & $5.4 \mathrm{kV}$ & $6.4 \mathrm{kV}$ & $9.4 \mathrm{kV}$ \\
$30 " \prime$ & $6.3 " \prime$ & $8.1 " \prime$ & $9.4 "$ \\
$40 "$ & $8.1 "$ & $8.5 "$ & $>9.4 "$
\end{tabular}

\section{（4）放電反応の生成物}

放電管は放電を継晩するに彷って，褐色将状の物貿が 膜状に放電間隙に附着し，その厚さは次第に増加し，と きには数力所に扔いて放電間隙を短絡して放電を不能に したことるむった。この物筫はシアン化水素のグロ一放 電の生成物と同様にパラシアンで女ることを認めた。ジ シソンはグロー放電の啰合と同㥞に全く生成されない。

放電化伴ない、放雪管内の気体の圧が減少すること区び 上述の上うにジシテシを生成しないことから，敎電炕よ って起る反応は少なくとも

$$
n \mathrm{HCN}={ }_{2}^{n} \mathrm{H}_{2}+(\mathrm{CN})_{n}
$$

を伴なっていることが推定される。苦し(1)式の反応の みが起っているならば，品る放雪条件下のシアン化水素 ○分解量を $x$ ，初湛度を $a$ と乙更何じ条件下の圧の減 少值を $\Delta p$ ，初玨を $p_{0}$ とすると，こ礼品間心は次の 関係が成立しなけ秃ばならない。

$$
x / a=2 \Delta p / p_{0}
$$

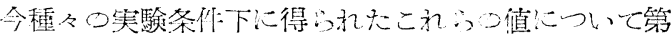

\begin{tabular}{|c|c|c|c|c|c|c|}
\hline 初 & 圧 & 鼠 & 流 & 放電哇間 & $2 \Delta p / p_{0}$ & $x / a$ \\
\hline \multicolumn{2}{|c|}{$20 \mathrm{~cm} \mathrm{Hg}$} & \multicolumn{2}{|c|}{$100 \mu \mathrm{A}$} & $600 \mathrm{sec}$ & 0.21 & 0.22 \\
\hline & 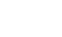 & 200 & "I & " & 0.40 & 0.38 \\
\hline & & 300 & " & " & 0.53 & 0.56 \\
\hline \multirow[t]{3}{*}{30} & & 100 & " & $"$ & 0.19 & 0.17 \\
\hline & 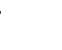 & 200 & " & " & 0.41 & 0.37 \\
\hline & 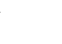 & 300 & $\prime \prime$ & " & 0.53 & 0.53 \\
\hline
\end{tabular}
策 2 表
2 表の結果を見ると,上記の関係がよく満たされ，従って 分解反応は(1)式に示されるもののみが起ることがわか る。な诎(1)式によって生成する水素が無声放電によっ て解離するために圧力の減少を示す㲘念が女ったので， 水素のみに対してジン化水素化対すると同じ条件にて 無声放電を行った处，圧の減少は起らないことを確め た。よって圧の減少は(1)式のみによるものと考えて差 支えない。

\section{(5) 分解速度}

シアン化水素の無声放電による分解はグロー，弧光両
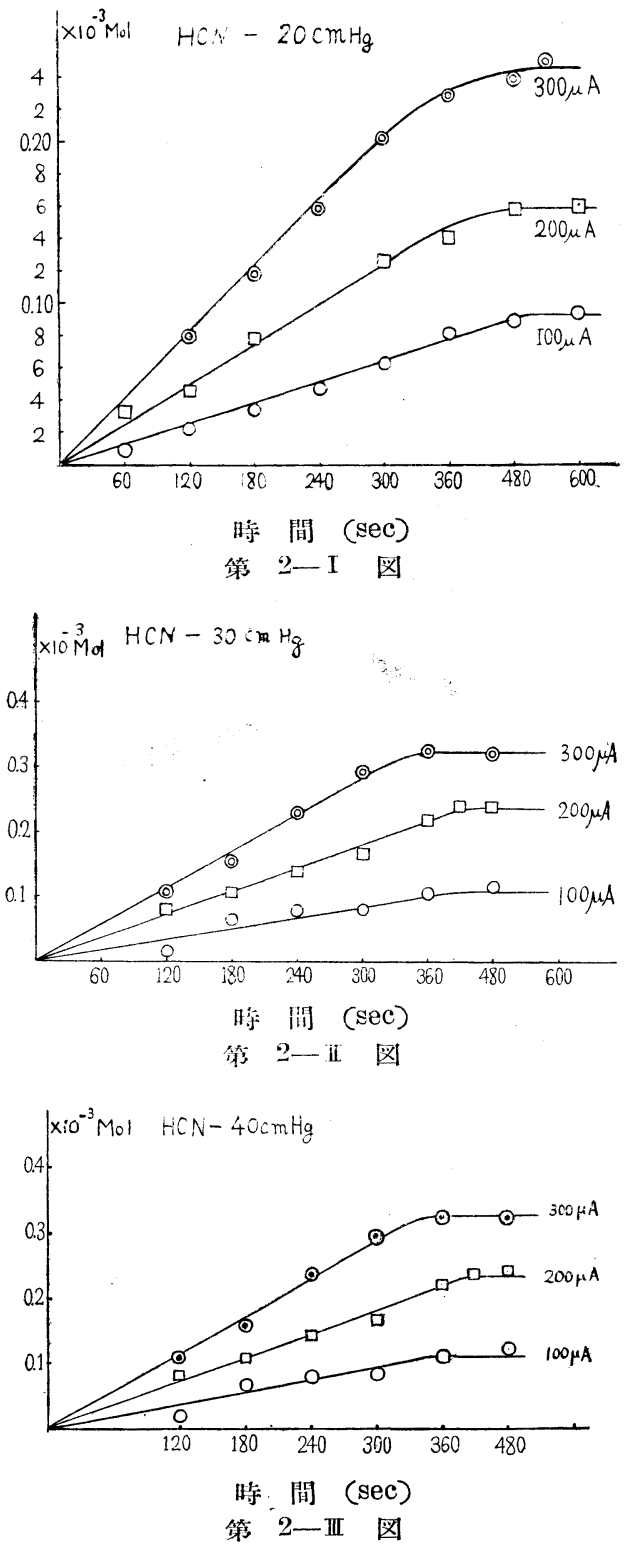
放電によるものとはかなり異なることを認せた。即ち一 般に放電開始後, 初区並びに放電電流によって異なるが， ある時間上内は分解量は放電時間に比例して増加し，そ の後は分解速度は次第に減少し，放電開始後 5 ６ 分後 には分解反応は停止する。第正四は放第電流をバラメー タとして分解量 $x$ を放電時間 $t$ 亿対して目盛ったもので むる。

$x$ が $t$ に比例する部分に打いて $x=k_{0} t$ と置けば， $k_{0}$ は零次反応の速度定数となる。 $k_{0}$ を初圧をパラメータ として放電電流 $I$ に対して区炇盛ると第 3 図が得られ， $I=0$ に执いて， $k_{0}=0$ となることから，速度定数 $k_{0}$ は 放電電流Iに比例して增加寸ることが和かる。

\section{(6) 分解率}

（5）に述べたように，分解反応が停止した場合に岕け るシアン化水素の分解量 $x$ の初湛度 $a$ に刘する比を分解 率とし，これを第 3 表に示した。これより分解率は同し

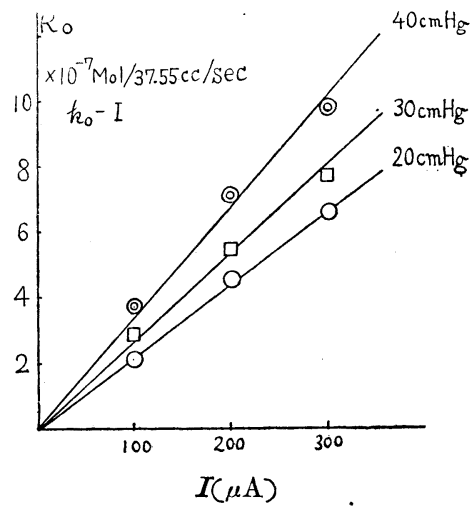

第 3 図

初圧に执いては，放電電流が大きい程増加することは認 められたが，シアン化水素1 やジシアンのグロー放電》。 に見られたように，放電電流に無関係に分解率が一定に 保たれるといった関係は見られなかった。

第 3 表 シアン化水素の分解率

\begin{tabular}{l|l|l|l}
\hline 電 流 & $100 \mu \mathrm{A}$ & $200 \mu \mathrm{A}$ & $300 \mu \mathrm{A}$ \\
初 圧 & & & \\
\hline $20 \mathrm{~cm} \mathrm{Hg}$ & 0.22 & 0.38 & 0.56 \\
$30 "$ " & 0.17 & 0.37 & 0.53 \\
$40 "$ & 0.19 & 0.25 & 0.36
\end{tabular}

要 約

（1）シアン化水素は無声放電によっても分解せら れ，グロ一放電と同様に水素及びパラシアンを生成する 3）第 5 㫰の予定
ことを認めた。但し分解速度等に関しては，グロー放電 の場合とかなりの相違がある。

（2）分解率汇関しては，グロ一放電偟られた関係 は全く認められなかった。

終りに臨んで終始烈篤なる御指導を睗わった鈴木桃太 郎教授並びに実験に協力せられた山里千代子嬢に謝意を

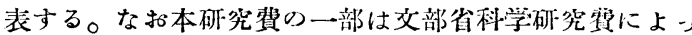
たことを牛し添える。

(昭和 28 年 4 月, 日本化学会第 6 年会(一部)讙演)

\section{（第 5 報）グロー放電によるジシアン の分解，重合反応}

\section{緒言}

著者は放電によるシアン化合物の生成反応について研 总を行い，これに関連してシアン化合物特にシアン化水

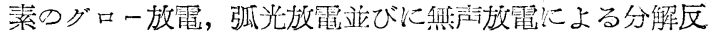
応を研究し，既にその一部を発表した。本馨においては シアン化水素と其に，シアン化合物を代表するジシアン の放電による分解，重合反応について䋸告する。

実験

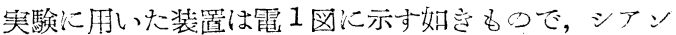
化水素の分解に用いたるのと略々同じで方る。反応管 $\mathrm{A}$ は直径 $2.4 \mathrm{~cm}$ ，内容積 $108.21 \mathrm{cc}$ で, $22.3 \mathrm{~cm}$ の距耀 に岁るアルミニウムの二つの電㥛をもっている。電源の 一次㑬電在は $50 \mathrm{~V}$ 这びに $100 \mathrm{~V}$ を鿟い, 最高 $15 \mathrm{kV}$

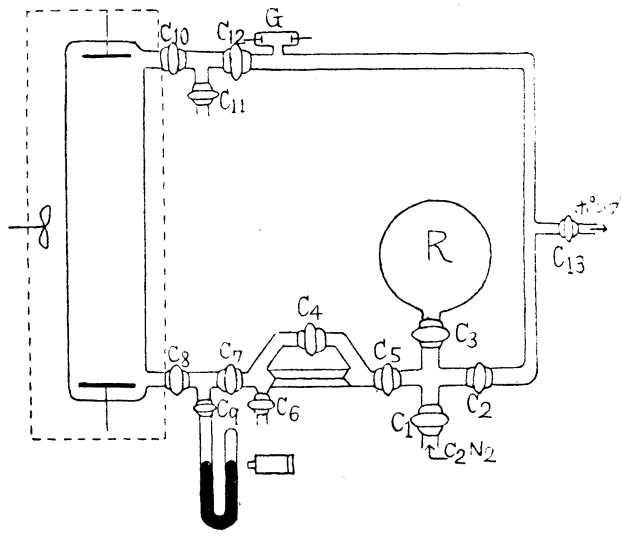

第 1 図

のネオントシンスを用いて舁在した。放電電流は一次, 二次兵実効値型榚密級アンメータを, 二次電圧は静電 電圧計を用いて测定した。ジシアンはシアン化水銀の熱 